\title{
Pengurusan Kecairan Institusi Kewangan Islam (IKI) Di Malaysia: Analisis Perbandingan Antara Keperluan International Islamic Liquidity Management (IILM) Berbanding Pasaran Wang Antara Bank Secara Islam (IIMM)
}

(Liquidity Management of Islamic Finance Management in Malaysia: Comparative analysis between International Islamic Liquidity Management (IILM) and Islamic Interbank Money Market)

\author{
Najibah Khairiyah Binti Shahabudin, ${ }^{\mathrm{a}, *}$ Kamaruzaman Noordin, ${ }^{\mathrm{a}}$ \\ a Akademi Pengajian Islam, Universiti Malaya. \\ *Corresponding author: najibabkhairiyab@gmail.com
}

\section{Article history}

Received: 2017-04-10

Received in revised form: 2017-08-14

Accepted: 2017-08-15

\begin{abstract}
Malaysia is a country that leads in the Islamic Financial sector. In fact, Malaysia is the first country that has established Islamic Interbank Money Market (IIMM) while banks in other countries only provide high liquidity instruments without platform. However, in 2010, International Islamic Liquidity Management (IILM) has been established to manage the liquidity globally. IILM is led by Malaysia because of its authority in Islamic Finance. Since its establishment, IILM manages the global liquidity through short term wakalah sukuk only. Thus, why is IILM needed if it only issues one instrument? In comparison, IIMM have many high liquidity instruments to meet the needs of IFI in Malaysia. In fact, IIMM is a strong platform for managing liquidity in Malaysia. By using the interview and longitudinal method, the researchers found out that IILM does not threaten the preexisting IIMM in Malaysia because both IILM and IIMM have different missions and visions. Therefore, IIMM is needed in Malaysia. However, IILM is not only needed in Malaysia but also globally. The world acceptance on the IILM's short-term instrument would help in solving the issues regarding the excess liquidity in IFI. However, IILM still have to make various improvements to achieve its own objectives.
\end{abstract}

Keywords: Liquidity management, International Islamic Liquidity Management (IILM), Islamic Interbank Money Market (IIMM). 


\begin{abstract}
Abstrak
Malaysia adalah sebuah negara yang maju ke hadapan dalam bidang kewangan Islam. Malahan, Malaysia juga merupakan negara pertama yang menubuhkan Pasaran Wang Antara Bank Secara Islam (IIMM) di saat bankbank Islam di negara lain hanya menawarkan instrumen mudah cair tanpa platform. Namun, pada tahun 2010, International Islamic Liquidity Management (IILM) telah ditubuhkan untuk menguruskan kecairan merentasi sempadan global. IILM dipengerusikan oleh Malaysia atas dasar kewibawaan Malaysia dalam bidang kewangan Islam. Sepanjang penubuhannya, IILM hanya menguruskan kecairan global melalui sukuk jangka pendek wakalah. Justeru, timbul persoalan sejauh mana keperluan terhadap IILM kerana ia hanya menerbitkan satu instrumen sahaja. Manakala IIMM mempunyai banyak instrumen mudah cair yang mampu memenuhi keperluan IKI di Malaysia. Malahan, IIMM juga adalah platform pengurusan kecairan di Malaysia yang kukuh. Dengan menggunakan metode temubual dan longitudinal, pengkaji mendapati bahawa IILM tidak menggugat kewujudan IIMM di Malaysia kerana mempunyai misi dan visi yang berlainan. IIMM masih diperlukan di Malaysia. Namun, IILM diperlukan bukan setakat di Malaysia, malah di peringkat global. Dengan adanya instrumen jangka pendek yang diterima oleh seluruh pelusuk dunia, ia mampu mengurangkan segala isu berkaitan dengan lebihan kecairan di IKI. Namun demikian, IILM perlu membuat pelbagai penambahbaikan untuk mencapai objektifnya yang tersendiri.
\end{abstract}

Kata kunci: Pengurusan Kecairan, International Islamic Liquidity Management (IILM), pasaran wang antara bank secara Islam (IIMM). 


\subsection{PENDAHULUAN}

Sistem Kewangan Islam di Malaysia telah mempunyai Pasaran Wang Antara Bank Secara Islam (Islamic Interbank. Money Market, (IIMM)) yang aktif. Malahan, Malaysia adalah hub kewangan Islam di dunia. Malaysia juga menyediakan persekitaran kawal selia yang cekap dan kondusif untuk Institusi Kewangan Islam (IKI). Namun, pada tahun 2010, International Islamic Liquidity Management (IILM) telah ditubuhkan di Malaysia sebagai satu institusi yang menguruskan kecairan merentasi sempadan global. Malaysia juga adalah antara negara yang menganggotai IILM. Justeru, penubuhan IILM dengan melibatkan Malaysia telah menimbulkan tanda tanya sejauhmanakah penglibatan IILM terhadap pengurusan kecairan Islam di Malaysia. Apakah peranan dan operasi sebenar IILM berbanding IIMM yang telah sedia ada beroperasi sejak sekian lama di Malaysia? Persoalan utama yang perlu dirungkai adalah di mana keperluan terhadap IILM kerana IIMM telah bertapak lama di Malaysia. Oleh itu, pengkaji akan menganalisis peranan dan operasi IILM dan IIMM di Malaysia. Kedua, pengkaji akan mengkaji statistik perkembangan instrumen jangka pendek yang telah diterbitkan oleh IILM dan IIMM. Kemudian, pengkaji akan mengkaji perbandingan antara keperluan terhadap IILM dan IIMM di Malaysia. Justeru, kajian ini telah distruktur dengan teratur mengikut objektif kajiannya iaitu dimulai dengan peranan dan operasi IILM dan IIMM di Malaysia. Dalam bahagian operasi juga turut dinyatakan jenis-jenis instrumen jangka pendek yang diterbitkan oleh IILM dan IIMM. Kemudian, struktur kajian diikuti pula dengan statistik perkembangan instrumen jangka pendek IILM dan IIMM. Akhirnya, kajian akan membincangkan perbandingan antara keperluan terhadap IILM dan IIMM di Malaysia dan kesimpulan secara keseluruhan.

\subsection{METODOLOGI}

Kajian ini menggunakan pendekatan kualitatif sebagai metode primer, manakala pendekatan kuantitatif sebagai metode sekunder. Bagi kajian terhadap keperluan IILM berbanding IIMM, pengkaji menggunakan metode primer. Ini kerana permasalahan yang dibangkitkan tidak dapat difahami dengan hanya menggunakan data kuantitatif semata-mata, sebaliknya memerlukan data kualitatif yang diperoleh daripada kaedah temubual. Manakala, bagi statistik perkembangan penerbitan instrumen IIMM dan IILM, ianya dianalisis dengan menggunakan pendekatan kuantitatif. Statistik ini dikaji dengan menggunakan kaedah longitudinal iaitu data yang dikumpul berasaskan satu jangka masa terhadap satu kumpulan sampel yang sama.

Dari segi informan pula, sebanyak lapan orang telah dipilih untuk sesi ditemubual. Pihak yang ditemubual terdiri daripada pihak IILM, pelabur utama IILM, pihak luar dan pakar Syariah. Kesemuanya dipilih kerana mempunyai penglibatan secara langsung dengan IILM dan mempunyai pengetahuan yang luas dalam bidang kecairan. Data daripada temubual tersebut pula telah dianalisis dengan menggunakan perisian Atlas Ti. Kaedah triangulasi juga turut menggunakan perisian tersebut. Data bagi statistik perkembangan instrumen telah diambil daripada portal IILM dan IIMM. Terdapat dua analisis yang dilakukan iaitu statistik perkembangan terbitan instrumen jangka pendek setiap tahun dan juga perbandingan terbitan instrumen setiap bulan antara dua tahun yang terkini. 


\subsection{PERANAN IIMM DALAM MENGURUSKAN KECAIRAN}

Pasaran Wang Antara Bank Secara Islam (IIMM) adalah salah satu pasaran yang penting dalam sistem kewangan Islam. Pasaran ini bersama pasaran-pasaran yang lain telah membentuk sistem kewangan Islam di Malaysia. Tujuan utama penubuhan pasaran wang antara bank ini adalah untuk menyediakan platform transaksi aset kewangan bagi penjual dan pembeli serta peminjam dan pemiutang. Dengan adanya platform IIMM, ia memudahkan pihak yang memerlukan kredit dan pihak yang mampu membekalkan dana dalam jangka masa yang pendek. Oleh itu, pasaran wang mampu untuk menyediakan peluang-peluang pelaburan bagi pihak yang mempunyai lebihan dana dan sebagai satu sumber bagi pihak yang mempunyai kekurangan dana.

Secara ringkasnya, terdapat tiga peranan IIMM iaitu:

Tempat pengurusan kecairan

Tempat urusniaga instrumen pasaran wang sekunder.

Tempat bagi BNM menjalankan polisi kewangan.

\section{a) Peranan IIMM Sebagai Tempat Pengurusan Kecairan}

Pasaran wang adalah tempat bagi Institusi Kewangan Islam (IKI) menguruskan kecairan mereka melalui pelaburan jangka pendek atau sumber pendanaan seharian. Dengan adanya pasaran wang IKIdapatmengekalkan kecairan optimum dengan memenuhi keperluan IKI lain pada bila-bila masa sahaja. Tambahan, IKI juga dapat menguruskan tekanan jangka pendek dan memberi pilihan kepada institusi ini untuk memilih instrumen yang sesuai dengan kehendak kecairan masing-masing. Institusi bukan kewangan pula boleh menggunakan pasaran wang ini untuk mengatasi masalah keperluan modal kerja berterusan dengan menerima dana jangka pendek. Selain itu, IKI boleh menguruskan kecairan mereka dengan kos pendanaan yang rendah dan menikmati pulangan pelaburan yang kurang berisiko (ISRA, 2016).

b) Peranan IIMM Sebagai Tempat Penjualan Instrumen Pasaran Wang Sekunder

Pasaran wang juga adalah tempat urusniaga instrumen pasaran wang sekunder. Jika terdapat bank yang tidak mahu memegang instrumen pasaran wang dalam tempoh setahun, maka bank tersebut boleh menjual instrumen itu di pasaran wang sekunder. Instrumen yang berada di pasaran wang sekunder ini mempunyai pelbagai tahap risiko, pulangan dan tempoh matang. Oleh itu, ia bergantung kepada IKI untuk membuat pilihan dari segi instrumen yang boleh menguruskan kecairan mereka dengan baik (ISRA, 2016).

c) Peranan IIMM Sebagai Tempat Bagi BNM Menjalankan Polisi Kewangan

Selain itu, pasaran wang juga adalah tempat bagi BNM untuk menjalankan polisi kewangan. BNM akan menggunakan operasi pasaran terbuka bagi IKI untuk menjual dan membeli sekuriti kerajaan. Melalui operasi pasaran terbuka juga, IKI boleh menggunakan pembiayaan jangka pendek terus kepada bank-bank lain ketika berdepan dengan situasi defisit. Dengan cara ini, BNM boleh memberi tanda aras dan menguruskan kecairan IKI dengan lebih baik. Segala perubahan pada tanda aras dan kecairan dalam pasaran wang akan mempengaruhi kecairan dan kadar keuntungan pada pasaran lain. Ini kerana, pasaran wang adalah platform pertama yang mendapat kesan daripada perubahan polisi kewangan, seterusnya kepada pasaran-pasaran jangka panjang yang lain seperti pasaran bon dan ekuiti (ISRA, 2016). 


\subsection{JENIS PASARAN WANG}

Terdapat 2 kategori pasaran wang iaitu:

i. Pasaran utama atau pasaran peringkat pertama.

ii. Pasaran kedua atau pasaran peringkat kedua.

Pasaran utama adalah pengeluaran instrumen yang baharu dan tidak dijual beli lagi. Keluaran baharu ini akan mencipta dan menamatkan tuntutan kewangan. Peserta-peserta dalam pasaran utama terdiri daripada pembekal pertama dan pengguna terakhir. Mereka ini akan mengumpul dana dengan menerbitkan sekuriti kepada agensi korporat atau kerajaan. Oleh demikian, hanya melalui pasaran pertama sahaja pengumpulan dana dilakukan. Dalam pasaran kedua pula, tiada aktiviti pengumpulan dana untuk penerbit (ISRA, 2016).

Pasaran kedua adalah berkaitan dengan pengeluaran lama daripada kegiatan bank dan instrumen yang telah dijual beli. Jenis ini tidak mencipta dan menamatkan tuntutan kewangan. Ia tidak memindahkan instrumen daripada peminjam kepada pembiaya. Tujuannya adalah untuk penjualan dan pembelian instrumen. Pemilik atau pemegang instrumen mudah tunai boleh menukarkan aset mereka kepada tunai tanpa mengalami sebarang kerugian. Ia adalah satu cara bagi pemilik instrumen yang memerlukan dana dengan segera untuk menampung pengeluaran wang oleh pelanggan (ISRA, 2016). Pasaran kedua ini mampu untuk menyokong pasaran utama dengan menyediakan mudah tunai dan maklumat kepada pemberi pinjam. Dengan adanya pasaran kedua, pembeli tidak perlu menunggu untuk membeli instrumen pada tarikh matang. Selain itu, peserta pertama juga boleh melabur dalam instrumen lain yang mempunyai pulangan yang tinggi tanpa menunggu tarikh matang.

\subsection{INSTRUMEN PASARAN WANG ISLAM}

Penawaran instrumen pasaran wang Islam di Malaysia bermula apabila bank-bank Islam hanya bergantung kepada satu instrumen sahaja, iaitu Sijil Pelaburan Kerajaan (GII) untuk menguruskan kecairan. Bank-bank Islam akan membeli sijil ini daripada BNM apabila terdapat lebihan kecairan dan menjual sijil ini apabila mempunyai kekurangan kecairan. Oleh kerana terdapat satu sahaja instrumen mudah cair, maka pengurusan kecairan adalah sangat terhad. Tambahan pula, tiada lagi pasaran kedua untuk menjual instrumen tersebut (Obyatullah Ismath. Bacha, 2008).

Selepas beberapa tahun penubuhan IIMM, ia mula menawarkan Pelaburan Interbank Mudarabah (MII) pada tahun 1996. Tujuan pengeluaran instrumen tersebut adalah untuk mengatasi masalah ketidaksepadanan antara aset dan liabiliti perbankan Islam. Pada tahun 1999 pula, BNM telah memperkenalkan kontrak bay' al-inah di mana BNM bertindak sebagai peminjam terakhir (lender of last resort) kepada bank-bank yang menghadapi masalah defisit. Pada tahun 1999 juga, tender pasaran wang muḍarabah telah diperkenalkan. Bank-bank Islam telah memasuki tender IIMM dengan membuat tawaran melalui sistem automatik penuh (FAST).

Melalui penyertaan tersebut, terdapat banyak instrumen pasaran wang yang telah diperkenalkan. Antaranya ialah Nota Rundingan Bank Negara (BNNN) pada tahun 2000, Instrumen Penerimaan Wadiah pada tahun 2002, Bil Perbendaharaan Islam Malaysia pada tahun 2004, Komoditi Murabahab Program (CMP) pada tahun 2007 dan Perjanjian Pelaburan Wadiah (WPA) pada tahun 2009. CMP yang diperkenalkan menjadikan transaksi pelaburan lebih jelas melaluinya. WPA pula dikeluarkan untuk melaraskan perjanjian pengambilan deposit daripada 
pelanggan korporat dengan bank-bank Islam dan pelaburan antara bank-bank Islam di bawah konsep wakalah(ISRA, 2016).

Kini instrumen pasaran wang yang diperkenalkan makin bertambah. Berikut adalah instrumen pasaran wang pada masa kini (IIMM, t.t):

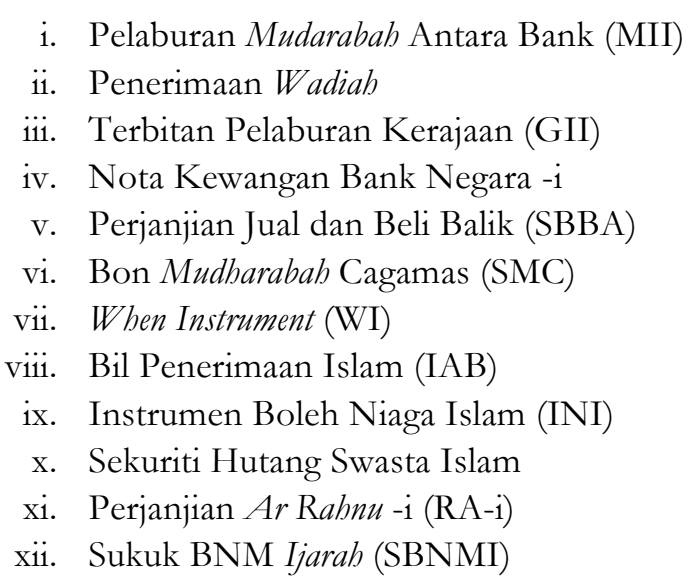

Namun kini, terdapat beberapa penciptaan instrumen pasaran wang yang baru iaitu:

i. Komoditi murabahah

ii. Pelaburan wakalab antara bank

iii. Kolateral murabahab

\subsection{STATISTIK PERKEMBANGAN PENERBITAN INSTRUMEN IIMM}

Perkembangan jualan instrumen-instrumen IIMM dapat dilihat daripada frekuensi saiz jualannya. Saiz jualan yang besar pada bulan-bulan tertentu menunjukkan kejayaan jualan instrumen pada bulan sebelumnya. Ini kerana hasil jualan pada bulan sebelum setelah ditolak dengan perbelanjaan lain akan digunakan untuk menerbitkan instrumen pada bulan berikutnya. Bagi melihat prestasi jumlah jualan kesemua instrumen IIMM dengan lebih jelas dan terkini, pengkaji telah menganalisisnya dan menyatakan dalam bentuk graf. Berikut adalah graf perkembangan penerbitan instrumen pasaran wang.

\section{RAJAH 1: Perkembangan Penerbitan Instrumen Pasaran Wang dari Januari 2014 Sehingga} Disember 2016

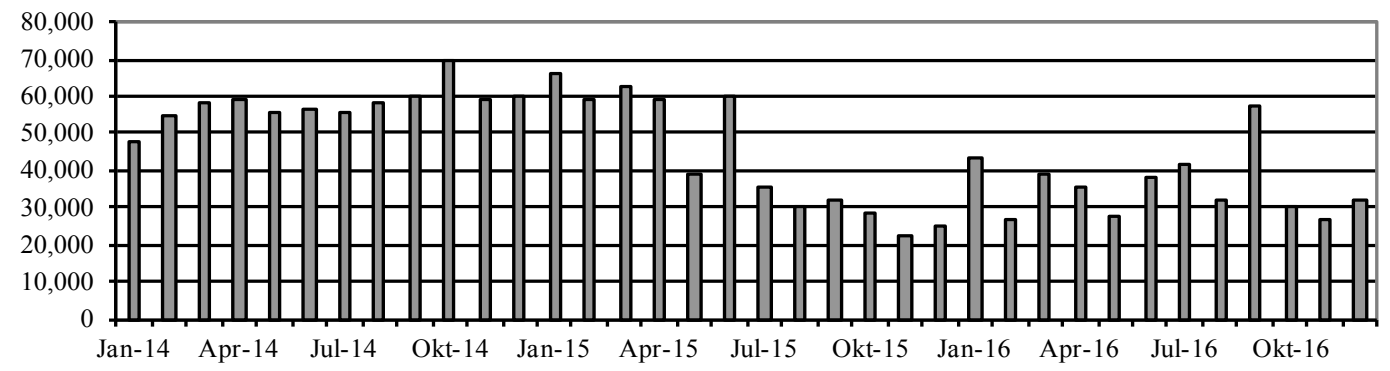

口Saiz Jualan Instrumen

Sumber: Diolah Daripada Portal Pasaran Wang Islam Antara Bank 
Statistik prestasi jualan intrumen-instrumen IIMM yang ditunjukkan adalah daripada bulan Januari, tahun 2014 sehingga bulan Disember, tahun 2016. Daripada bulan Januari, tahun 2014 sehingga bulan April, tahun 2015 menunjukkan prestasi jualan yang sangat memberangsangkan. Namun, bermula pada bulan Mei, tahun 2015 menunjukkan penurunan prestasi yang sangat ketara iaitu daripada RM59,407 kepada RM38,731. Kemudian pada bulan Jun, tahun 2015, prestasi jualan telah meningkat dengan mendadak kepada RM59,741. Selepas daripada itu, prestasi di IILM adalah menurun melainkan pada bulan September, tahun 2016.

Daripada analisis pengkaji, prestasi jualan instrumen yang mulai menurun pada pertengahan tahun 2015 adalah kerana harga minyak mentah yang jatuh. Negara-negara pengeksport minyak mentah seperti Malaysia semestinya akan terkesan dengan harga minyak mentah. Ini menyebabkan kerajaan Malaysia tiada pilihan selain mengurangkan perbelanjaan pelaburan. Kesannya, penerbitan sukuk dan tawaran pembiayaan akan berkurangan (Mahmoud Kassim, 2016). Berikutan kejatuhan harga minyak mentah ini, saiz jualan instrumen-instrumen IIMM pada tahun 2015 juga mengalami penurunan. Namun, pada tahun 2016, harga minyak mentah masih tidak stabil. Antara faktornya adalah kerana negara-negara pengeksport tidak mahu mengurangkan pengeluaran minyaknya. Oleh itu, pengeluaran minyak setiap tahun menjadi banyak dan menyebabkan harganya menjadi murah.

Berikutan dengan faktor ekonomi ini, ia akan memberi kesan kepada pengeluaran instrumen kewangan di mana saiz jualan instrumen IIMM juga akan menjadi tidak menentu. Ada ketika saiz jualan ini meningkat dan ada ketikanya menurun pada bulan-bulan tertentu. Hal ini juga bertepatan dengan laporan daripada Moody's yang mengatakan bahawa terbitan instrumen sukuk jangka pendek pada 2016 agak kurang kerana keadaan ekonomi yang telah perlahan dalam pasaran. Perkara ini juga disebabkan oleh keputusan BNM untuk mengurangkan pengeluaran instrumen sukuk bermula tahun 2015 walaupun secara tradisinya Malaysia adalah pengeluar instrumen sukuk yang paling besar (Rupa Damodaran, 2016). Di bawah pula adalah perbandingan transaksi jualan instrumen-instrumen IIMM antara tahun 2014 dan 2015:

\section{RAJAH 2: Perbandingan Transaksi Jualan Instrumen-Instrumen IIMM Antara Tahun 2014 Dan} 2015.

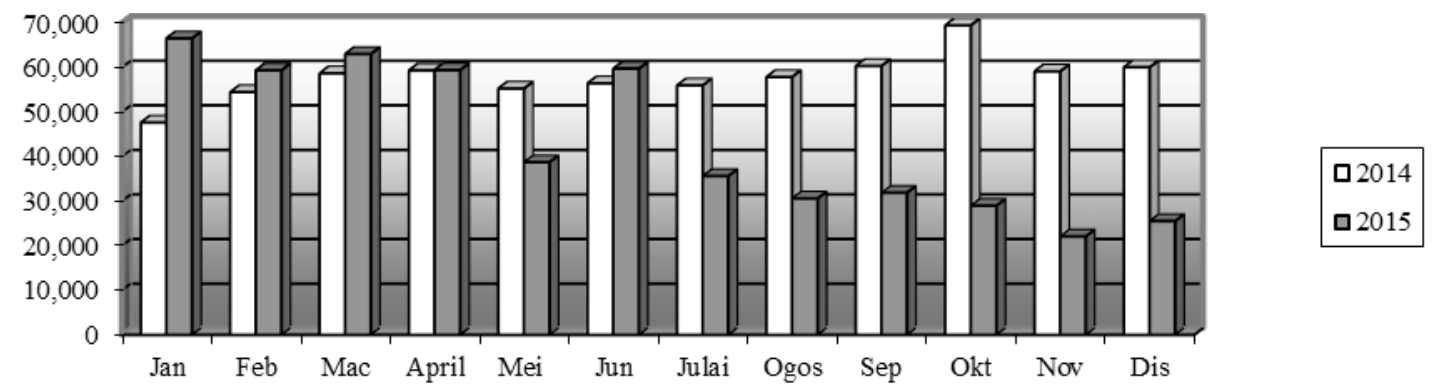

Sumber: Diolah Daripada Portal Pasaran Wang Antara Bank Secara Islam

Rajah 2 di atas menunjukkan keupayaan jualan kesemua jualan 2014 mengatasi 2015. Ini menggambarkan bahawa penurunan jualan instrumen bermula daripada tahun 2014. Pada bulan Mei 2014, jualan instrumen adalah sebanyak RM55, 283 berbanding RM38, 731 pada tahun 2015. Kemudian, jualan Jun 2015 melonjak naik mengatasi Jun 2014. Namun, pada bulan berikutnya perbezaan yang begitu ketara amat kelihatan. Prestasi jualan kesemua instrumen IIMM pada Julai 2015 sehingga Disember 2015 telah menurun. Jualan kesemua instrumen pada tahun 2015 hanya dalam lingkungan RM20 ribu sehingga RM30 ribu berbanding 2014 yang mencapai sebanyak RM50 ribu sehingga RM60 ribu. 
Faktor penurunan jualan instumen ini juga adalah disebabkan oleh kejatuhan minyak mentah global yang berada di luar jangkaan kebanyakan pihak. Ia mulai menurun sejak pertengahan tahun 2014. Penurunan harga minyak pada tahun 2014 dipengaruhi oleh permintaan yang lemah berbanding jangkaan. Pada tahun 2015 pula, kejatuhan harga minyak mentah terjadi disebabkan oleh lebihan bekalan yang terlalu banyak. Menurut laporan Pertubuhan Bangsa-Bangsa Bersatu (PBB), kejatuhan harga minyak dunia pada tahun 2015 adalah hampir 60\%, manakala harga komoditi pula 20\%. Kadar pertumbuhan ekonomi dunia adalah lebih menurun iaitu sebanyak 2.4\% pada tahun 2015 berbanding 2.6\% pada tahun 2014. Tahun 2015 adalah tahun terburuk bagi harga minyak sedekad.

\subsection{PERANAN IILM DALAM MEMBANGUNKAN KECAIRAN ISLAM MELALUI PENERBITAN SUKUK}

Setelah mengetahui peranan, operasi dan statistik perkembangan instrumen jangka pendek IIMM. Berikut pula adalah mengenai IILM. Terdapat tiga peranan utama IILM iaitu:

1. Tempat membangunkan instrumen mudah cair

2. Tempat memenuhi keperluan kecairan bank-bank Islam

\subsection{PERANAN IILM DALAM MEMBANGUNKAN INSTRUMEN MUDAH CAIR}

\subsubsection{Peranan dalam mencipta sukuk jangka pendek}

IILM menerbitkan sukuk pada setiap tiga bulan dalam tempoh programnya. Terbitan sukuk IILM sebanyak tiga bulan sekali kerana ianya merujuk kepada tanda aras daripada LIBOR. Kelebihan daripada terbitan tiga bulan sekali ini ialah mendapat deposit daripada pelabur-pelabur dengan harga pasaran yang rendah. (Iam Nazir Ibrahim, 25 Februari 2016). Ini bermakna, IILM tidak perlu membayar kadar keuntungan kepada pelabur-pelabur dengan nilai yang tinggi.

Tambahan pula, di pasaran wang antara bank, bank-bank sukar untuk melabur dalam tempoh yang panjang. Kebiasaannya, bank dapat melabur untuk tempoh 3 atau 6 bulan sahaja. Ini kerana, bank-bank yang mahu melabur juga hanya mendapat pembiayaan dalam tempoh yang singkat sahaja. Apabila IILM menerbitkan sukuk jangka pendek, ia akan memudahkan bank-bank untuk mendapat pembiayaan bagi membeli sukuk IILM. Malahan, pasaran kewangan Islam sangat memerlukan aset yang mempunyai tempoh jangka pendek untuk aktiviti pelaburan. Dana pembiayaan yang mereka peroleh untuk jangka masa pendek hanya mampu untuk dilaburkan dalam instrumen berjangka pendek sahaja (Iam Nazir Ibrahim, 25 Februari 2016).

\subsubsection{Peranan IILM dalam mendapatkan aset sandaran}

Antara peranan IILM yang lain ialah mendapatkan aset daripada negara-negara yang menyertainya dan juga bank pembangunan. Aset yang terlibat bukan sahaja daripada bank pusat tetapi juga melibatkan aset negara (Musa Hasan Abdul Basser, 11April 2016). Apabila melibatkan banyak aset negara, pelbagai prosedur yang perlu dijalankan bagi menjaga aset negara-negara tersebut. Disebabkan itu, ada sesetengah negara yang mengeluarkan pendapat supaya tidak didedahkan kategori aset sandaran bagi penerbitan sukuk yang telah diberi oleh mereka (Mohd Daud Bakar, 9 Jun, 2016).

Selain daripada tugas mendapatkan aset, IILM juga perlu mengenal pasti aset yang mempunyai penarafan yang tinggi. Ini selaras dengan kehendak Basel III ataupun mandat IILM 
yang mahukan instrumen sukuk yang dihasilkan adalah berkualiti tinggi dan mudah cair. Walau bagaimanapun, terdapat cabaran bagi IILM untuk menghasilkan sukuk seperti yang digariskan oleh Basel III kerana perlu memperoleh aset-aset sebagai sandaran kepada dana pelaburan mereka. Dengan kata lain, IILM tidak boleh mengeluarkan sukuk sesuka hati. Mereka mestilah mengeluarkan sukuk pada jumlah dan tempoh yang sesuai mengikut kehendak pasaran. Bagi sukuk biasa, mereka boleh menerbitkan sukuk pada bila-bila masa sahaja selagi mana terdapat projek yang mahu dibangunkan. Tetapi, bagi IILM, mereka perlu mengenal pasti di mana tempat yang perlu mereka labur terlebih dahulu (Mohd Daud Bakar, 9 Jun 2016).

\subsubsection{Peranan dalam memastikan instrumen yang diterbitkan patuh syariah}

Bank-bank Islam tiada masalah dari segi pendanaan kerana mempunyai tunai yang banyak. Namun, apabila memegang tunai yang banyak memerlukan deposit insuran patuh syariah. Ketiadaan deposit insuran yang patuh syariah mendorong bank-bank Islam untuk menggunakan akaun pelaburan keuntungan bersama (PSIA) atau mengurangkan tempoh masa yang panjang untuk pembiayaan (Dana Kewangan Antarabangsa (IMF, 2015).

Usaha IILM dengan mencipta instrumen patuh syariah berjangka pendek memudahkan IKI untuk menguruskan kecairan dan mendapat keuntungan yang tinggi (Dana Kewangan Antarabangsa, 2015). Oleh itu, IILM telah memainkan peranan yang besar untuk mengatasi masalah utama bank-bank Islam iaitu kekurangan instrumen yang cekap, patuh syariah, mematuhi Basel III dan boleh merentasi sempadan (Musa Hasan Abdul Basser, 11 April 2016).

Sukuk yang diterbitkan IILM ini tidak mengikut panduan AAOIFI (Musa Hasan Abdul Basser, 11 April 2016; Ramadhan Fitri Ellias, 8 Mac 2016). IILM hanya menerbitkan sukuk yang ditentukan oleh penasihat syariahnya sahaja (Iam Nazir Ibrahim, 25 Februari 2016; Musa Hasan Abdul Basser, 11 April 2016; Nazim Mohd Nor, 7 Mac 2016). Ini kerana IILM mempunyai banyak pemegang saham dari pelbagai pelusuk negara. Ini bermakna, IILM perlu menerbitkan sukuk yang dapat diterima oleh kesemua negara yang menjadi pemegang sahamnya. Sesetengah negara tidak menerima pakai garis panduan Auditing Accounting and Auditing Organization for Islamic Financial Institutions (AAOFI), seperti Indonesia. Indonesia mempunyai dewan syariahnya yang tersendiri, begitu juga dengan Qatar yang tidak menerima pakai garis panduan AAOIFI secara keseluruhannya. Dari perspektif syariah, IILM berkemampuan untuk menerbitkan instrumen yang mempunyai penanda aras tersendiri. Penanda aras ini menyebabkan kesemua negara boleh menyertainya (Ramadhan Fitri Ellias, 8 Mac 2016).

Namun, tidak bermakna sukuk yang tidak mengikut garis panduan AAOIFI tidak boleh dipasarkan secara global. Penasihat syariah yang menilai sukuk IILM adalah dipilih oleh pemegang saham IILM. Tambahan, penasihat syariah IILM terdiri daripada orang yang mempunyai kepakaran dalam menilai kepatuhan syariah seperti Daud Bakar. Daud Bakar bukan sahaja menjadi penasihat syariah IILM, malah juga kepada Bank Negara Malaysia, Suruhanjaya Sekuriti, bank-bank luar negara dan mempunyai syarikat perundingan yang terbuka untuk seluruh institusi kewangan di pelusuk negara. Oleh itu, terbitan sukuk yang dinilai oleh beliau senang diterima oleh pasaran secara global (Iam Nazir Ibrahim, 25 Februari 2016) 


\title{
7.2 PERANAN IILM DALAM MEMENUHI KEPERLUAN KECAIRAN BANK- BANK ISLAM
}

\subsubsection{Peranan IILM dalam memenuhi keperluan kecairan IKI di Malaysia}

IILM akan membantu pengurusan kecairan IKI dengan mengambil lebihan dana untuk dilaburkan dalam sukuk. Ini selaras dengan objektif penubuhan IILM iaitu untuk memenuhi keperluan kecairan yang berbeza di antara IKI (Musa Hasan Abdul Basser, 11 April 2016). Pelbagai negara yang berurusniaga dengan IILM termasuk IKI daripada Malaysia iaitu CIMB dan Maybank Berhad. Walau bagaimanapun, IKI ini mestilah mempunyai tahap penarafan yang tinggi dan seterusnya mampu untuk membeli sukuk IILM dalam mata wang dolar (Iam Nazir Ibrahim, 25 April 2016). Bagaimanapun, kenyataan ini berlainan pula dengan penyataan Ramadhan Fitri Ellias iaitu:

\begin{abstract}
"Semua bank kat Malaysia ni, dia ada pendedahan dia, cuma kecil atau besar. Dia sebenarnya kalau kat Malaysia ni, kita boleh terlibat sebab Malaysia negara yang import eksport dia agak tinggi. Jadi, import eksport ni, awak tak boleh lari dari mata wang yang berbeza, terutamanya dolar. Cuma isunya adalah satu bank untuk transaksi dolar, setakat 50 dia boleh bagi. Dia macam Maybank, dia boleh pergi sampai 1 bilion lebih. Jadi, perbezaan dia ialah saiz. ataupun orang kata limit yang dia boleh ada pada USD".
\end{abstract}

Oleh itu, semua IKI di Malaysia mempunyai pendedahan terhadap dolar. Namun isunya hanya sama ada dalam jumlah yang besar atau kecil. Justeru, kesemua IKI di Malaysia mampu untuk membeli sukuk yang diterbitkan oleh IILM.

\subsubsection{Peranan IILM untuk memastikan IKI mempunyai daya tahan untuk menghadapi krisis ekonomi seperti krisis ekonomi 2007}

Adalah suatu kemestian bagi IILM untuk bersedia bagi menghadapi krisis secara tidak diduga. Bagi mengelakkan risiko ketidakcairan berlaku, IILM mempunyai kriteria yang membolehkannya bersedia untuk menghadapi krisis ekonomi. Kriteria tersebut adalah seperti berikut (Musa Hasan Abdul Basser, 11 April, 2016):

\footnotetext{
i. Memainkan peranan dalam pasaran.

ii. Mempunyai instrumen jangka pendek.

iii. Mempunyai tunai.
}

Sukuk IILM adalah sukuk yang mampu memberi kecairan kepada IKI dalam menghadapi situasi mengejut seperti krisis ekonomi. Malahan, BNM juga telah mengiktiraf sukuk IILM dengan menerimanya sebagai kategori aset mudah cair di mana ianya boleh dijual apabila terjadinya krisis ekonomi ataupun tekanan kecairan di bank. Ini kerana penarafannya adalah tinggi dan ianya berjangka pendek (Iam Nazir Ibrahim, 25 Februari 2016).

Namun, tiada jaminan bahawa sukuk IILM dapat menyelesaikan masalah kecairan jika krisis ekonomi berulang kembali. Tetapi, ianya adalah usaha termampu yang boleh dilakukan oleh IILM untuk mengurangkan risiko ketidakcairan. Jika krisis tersebut berlaku lagi, IKI yang mempunyai sukuk IILM boleh menjual sukuk tersebut dengan begitu mudah dan mendapatkan tunai. Justeru, ia memberi kelebihan kepada IKI yang memegang sukuk IILM ketika krisis ekonomi. Penjelasan ini dibuat oleh Mohd Kamal Abd Karim dengan menyatakan bahawa;

"Risiko tersebut tidak pernah berlaku lagi. Jadi, kita tidak mampu menilai kemampuan sukuk. IILM tersebut" 


\subsection{PROGRAM PENERBITAN SIJIL SUKUK JANGKA PENDEK IILM}

Sukuk ILM dicipta untuk menggantikan US trade bill yang digunakan secara meluas sebagai alat kecairan. Sukuk ini dinamakan dengan sukuk 'danamodal' ketika diterbitkan. Kelebihannya adalah boleh memenuhi keperluan domestik mahupun di luar negara. Ini akan memudahkan mana-mana IKI untuk menguruskan lebihan dana mereka (BNM, 2013).

Penerbitan setiap siri sukuk IILM adalah bawah satu program sukuk. Amaun yang diterbitkan daripada program ini mestilah tidak melebihi 3 bilion USD (IILM, 2016) dan 5 tahun 8 bulan (DDCAP Group, 2014). Jumlah amaun itu telah dibahagikan kepada beberapa sub untuk melengkapkan jumlah 3 bilion dan dalam tempoh masa 5 tahun 8 bulan tersebut (Iam Nazir Ibrahim, 25 Februari 2016). Program ini akan matang pada 31 Disember 2018 (DDCAP Group, 2014). Setelah tamatnya program ini, IILM boleh menawarkan program penerbitan sukuk dalam jumlah yang lain pula.

Struktur sukuk dalam program ini adalah berasaskan kepada kontrak wakalah. Dalam kontrak wakalah, penerbit akan mewakilkan dirinya bagi pihak pemegang sijil sukuk untuk memohon penerbitan sijil sukuk tersebut (IILM, 2016). Tetapi dengan adanya program ini, penerbit tidak perlu memohon kepada Suruhanjaya Sekuriti Malaysia setiap kali mahu menerbitkan sukuk. Penerbit hanya perlu memohon sekali sahaja untuk suatu tempoh program sukuk (Iam Nazir Ibrahim, 25 Februari 25, 2016).

\subsection{OPERASI PENERBITAN SUKUK}

Sebelum berlaku operasi penerbitan sukuk, IILM akan mengadakan perbincangan dengan negara-negara yang telah menyertainya seperti Qatar, Luxemburg dan sebagainya. Ini kerana negara-negara ini adalah penyumbang kepada aset sandaran bagi penerbitan sukuk IILM. Kemudian, negara-negara tersebut perlu melabelkan taraf aset tersebut. Apabila telah diputuskan bahawa aset tersebut dalam kategori A1, maka mereka akan mengeluarkan sukuk tersebut dalam bentuk program selama 5 tahun atau 10 tahun. Bagi aset yang mendapat penarafan yang rendah seperti A2, mereka cuba mendapatkan surat jaminan (LG) seperti daripada ADB di Manila untuk menyakinkan pihak pelabur sukuk. Setelah mendapat kesepakatan tentang taraf penarafan aset daripada negara-negara lain, maka mereka akan meneruskan operasi penerbitan sukuknya (Mohd Daud Bakar, 9 Jun 2016).

Turutan operasi bagi menerbitkan sukuk IILM adalah seperti berikut (Musa Hasan Abdul Basser, April 11, 2016):

i. Perbincangan dengan pengedar utama.

ii. Perjanjian dan persepakatan.

iii. Kontrak - Berkenaan dengan syarat perjanjian dengan IILM, harga, kriteria sukuk dan soalan-soalan berkaitan.

iv. Terbitkan sijil sukuk IILM.

v. Menyerahkan kuasa kepada pemegang amanah.

vi. Pembelian sukuk IILM.

vii. Penilaian proses penerbitan sukuk mengikut terma dan syarat yang ditetapkan 


\subsection{STRUKTUR WAKALAH}

Struktur sukuk wakalah IILM adalah seperti berikut:

i. Pengedar Utama akan memberi dana untuk dilaburkan dalam sukuk IILM.

ii. IILM akan menerbitkan sukuk jangka pendeknya.

iii. SPV iaitu 'BNP Paribas Securities Services' akan memegang aset-aset. Aset tersebut diperolehi daripada setiap pemegang saham atau negaranegara yang menyertai IILM termasuk IDB. SPV telah melantik IILM sebagai wakil untuk mengumpul aset, mendapatkan bayaran daripada aset obligor dan beberapa perkhidmatan lain berkaitan dengan aset sandaran.

iv. Aset ini telah disumbangkan oleh negara-negara anggota IILM. Aset ini juga akan memberi kupon dan dividen kepada pengedar utama atau pelabur.

Rajah berikut menjelaskan struktur wakalah bagi IILM:

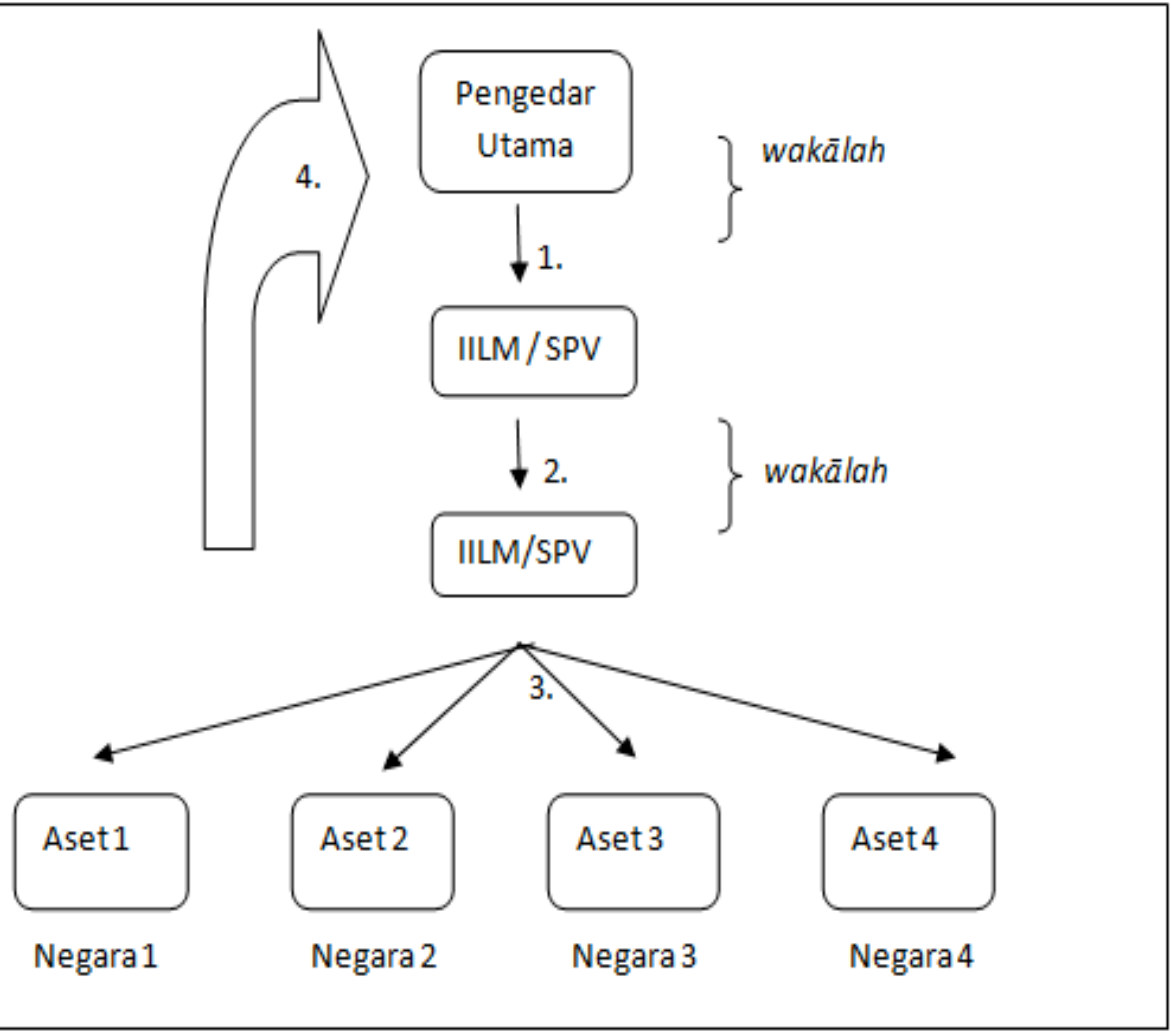

Sumber: Diambil daripada temubual bersama Nazim Mohd Nor

\subsection{PERBEZAAN IIMM DAN IIMM}

Secara keseluruhannya, IIMM digambarkan sebagai suatu pasaran atau platform bagi bank-bank Islam untuk menjalankan perniagaan. Bank-bank Islam yang berurusniaga instrumen jangka pendek sesama mereka akan dinamakan Pasaran Wang Antara Bank Secara Islam (IIMM). Disebabkan itu, IIMM tidak berdaftar sebagai sebuah pertubuhan seperti IILM. IIMM adalah satu entiti yang mempunyai transaksi urusniaga. IIMM juga tidak mempunyai organisasi yang 
formal untuk melakukan dagangan seperti di Bursa Malaysia. Apabila IIMM berhubung dengan bank-bank Islam untuk bertransaksi, secara langsung IIMM telah menyertai pasaran kewangan Islam (Iam Nazir Ibrahim, 25 Februari 2016).

Kamal Abdul Karim menyatakan bahawa

\begin{abstract}
"Bank-bank ini di bawah Bank. Negara punya akta, jadi dalam akta ini diorang boleh bertraksaksi antara diorang. Dia bukan macam platform Bursa Malaysia yang kita nampak. Platform dia wujud, tapi dia bukan firikal platform. Maksudnya ada kemudahan boleh pinjam-meminjam. Tolongmenolong, tapi tak nampak platform, fizikal. Tapi, kita tabu ada platform untuk pinjam antara satu sama lain. Macam itulah pasaran antara bank"” (Mohd Kamal Abdul Karim, 14 Mac 2016).
\end{abstract}

IILM pula adalah seperti sebahagian daripada IIMM di mana ia hanya menerbitkan sukuk jangka pendek bagi kemudahan kecairan institusi kewangan (Iam Nazir Ibrahim, 25 Februari 2016). IIMM pula memfokuskan kepada deposit untuk pasaran interbank Mudarabah, platform untuk terbit dan niagakan instrumen jangka pendek dan sistem penjelasan cek (ICCS). Manakala IILM hanya menerbitkan sukuk jangka pendek wakalah sahaja.

Bank-bank dalam IIMM berinteraksi berdasarkan komunikasi penjual yang diluluskan oleh BNM. Hal ini kerana, setiap transaksi perlu direkodkan oleh dokumen yang diluluskan. Terdapat 3 cara komunikasi di IIMM iaitu:

1. Telefon yang boleh direkod.

2. Broker yang diluluskan dan direkod melalui email dan sebagainya.

3. Perbualan melalui skrin perdagangan (trading screen) yang diluluskan oleh BNM seperti bloomberg, routers trading screen

Kesemua alat komunikasi ini perlu diluluskan untuk mengelakkan daripada berlakunya perselisihan faham apabila berinteraksi dan juga untuk mengenal pasti transaksi yang dijalankan. Setiap kali perbualan, alat komunikasi ini akan mengeluarkan dokumen sebagai bukti transaksi (Mohd Kamal Abdul Karim, 14 Mac 2016).

Kesimpulannya, IILM dan IIMM adalah dua perkara yang berbeza. Perbezaan yang ketara adalah IILM ialah institusi, manakala IIMM adalah pasaran. IILM adalah institusi yang menerbitkan instrumen mudah cair. Manakala IIMM pula adalah institusi yang menghubungkan penerbit instrumen mudah cair dan pembeli instrumen tersebut.

\title{
12.0 STATISTIK PERKEMBANGAN PENERBITAN SUKUK IILM
}

Rajah 3 menunjukkan graf perkembangan penerbitan Sukuk IILM dari awal penerbitan iaitu Ogos 2013 sehingga Mei 2016. Daripada rajah tersebut, ianya menunjukkan penerbitan sukuk dari tahun 2013 sehingga Januari 2016 adalah agak mendatar iaitu di antara 500 juta USD hingga 1 bilion USD. Namun, penerbitan sukuk pada bulan Februari dan Mei 2016 telah mula melebihi 1 bilion iaitu sebanyak 1.34 bilion. Peningkatan ini menunjukkan prestasi IILM yang semakin meningkat. Sebelum ini, saiz program sukuk IILM adalah sebanyak 2 bilion. Namun, amaun bagi program sukuk ini telah bertambah sebanyak 3 bilion bagi tahun 2016. Saiz amaun ini bertambah ekoran daripada pertambahan aset sandaran bagi penerbitan sukuk IILM. 


\section{RAJAH 3: Graf Perkembangan Penerbitan Sukuk IILM}

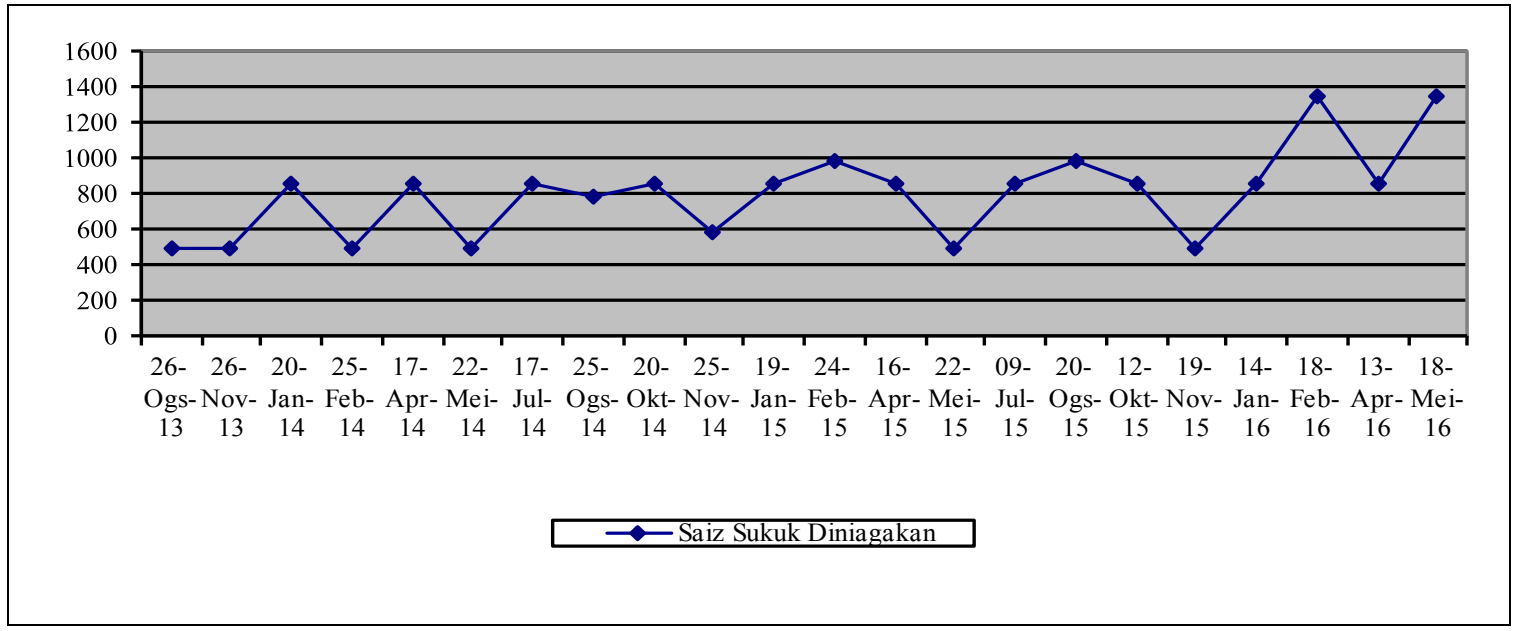

Sumber: Diambil daripada web International Islamic Liquidity Management Corporation (IILM)

Dengan pertambahan aset sandaran ini telah menunjukkan bahawa IILM mampu melabur 3 bilion USD ke dalam aset-aset kerajaan. Ini kerana aset-aset kerajaan ini tidak mudah untuk diperoleh kerana ia adalah aset-aset negara yang perlu dijaga. Tambahan, aset negara yang diterima oleh IILM perlu bertaraf A1, A2 atau A. Justeru, dengan bertambahnya amaun saiz program penerbitan sukuk IILM menggambarkan bahawa IILM mampu untuk menambah saiz penerbitan programnya dari tahun ke tahun. Kelebihan pertambahan amaun ini bukan sahaja mampu menerbitkan sukuknya dalam saiz yang besar, malah setiap sebulan. Selain itu, ia mampu menyelesaikan banyak perkara yang berpunca daripada masalah kekurangan aset sandaran kerajaan. Sebagai contoh, pengaktifan pasaran kedua dan pertambahan peserta atau dalam penerbitan sukuk IILM.

Pada tahun-tahun akan datang, pengedar utama sukuk IILM juga mampu untuk mengaktifkan pasaran kedua dengan menjual sukuk tersebut kepada pihak lain. Hal demikian kerana kemungkinan had amaun pelaburan bagi sesebuah IKI terhadap sukuk IILM telah bertambah. Malah, had amaun tersebut mungkin melebihi keperluan kecairan bagi institusinya. Justeru, apabila ia melebihi keperluan, IKI akan membuat keputusan untuk menjualnya kepada pihak lain dan seterusnya akan menjana keuntungan kepadanya.

Selain itu, IILM dapat meluaskan jumlah peserta atau pelabur untuk menyertai IILM. Hal ini berikutan apabila IILM dapat memperbanyakkan aset sandaran bagi penerbitan sukuknya. Pertambahan aset sandaran ini juga akan membuka ruang bagi peserta atau pelabur lain yang tidak mempunyai penarafan yang tinggi ataupun kurang pendedahan terhadap mata wang USD bagi menyertai IILM. Oleh yang demikian, dengan bertambahnya amaun bagi program penerbitan sukuk IILM dan saiz penerbitan sukuk IILM setiap bulan memperlihatkan prestasi IILM yang semakin meningkat dari semasa ke semasa. 
RAJAH 4: Saiz Sukuk Yang Diterbitkan Pada Tahun 2014 Dan 2015

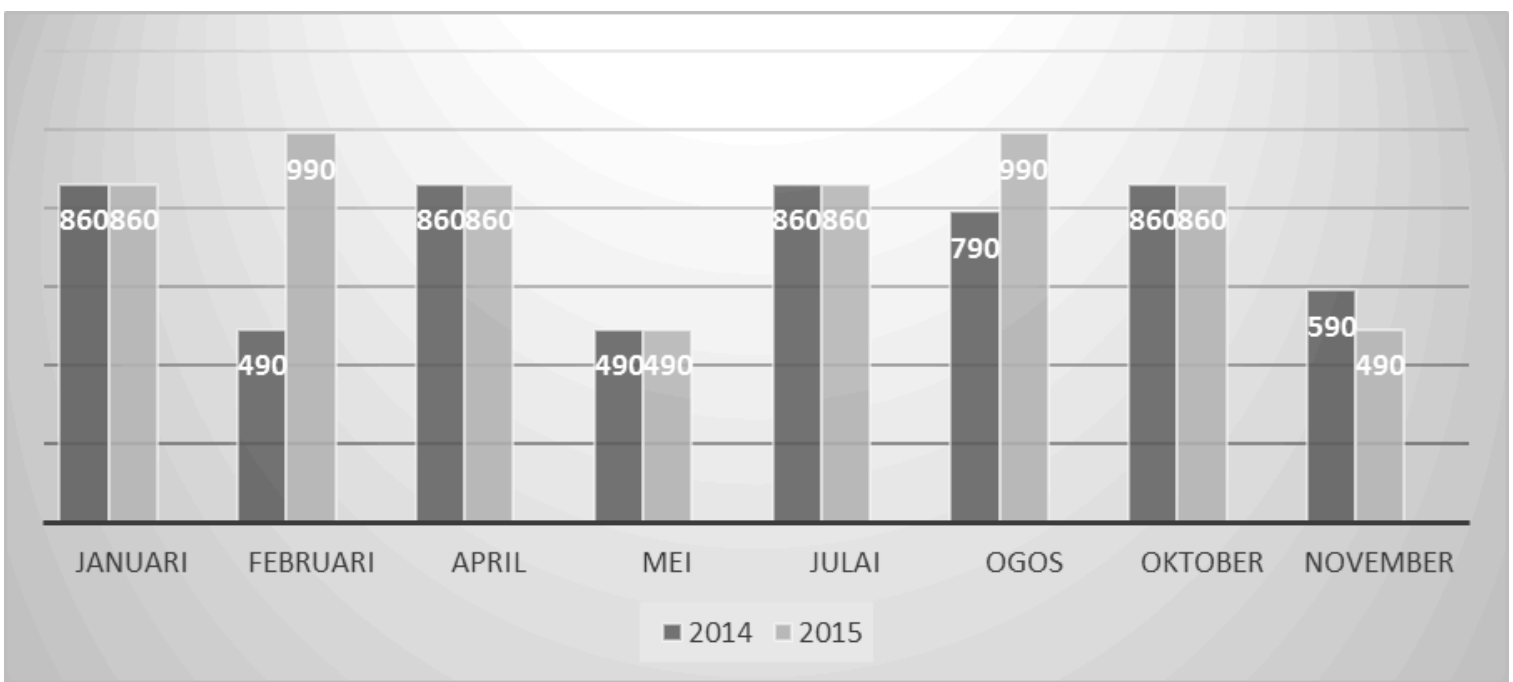

Sumber: Diambil daripada web International Islamic Liquidty Management Corporation (IILM)

Rajah 4 di atas menunjukkan perbezaan saiz sukuk yang diterbitkan pada tahun 2014 dan 2015. Secara keseluruhannya, saiz sukuk yang diterbitkan adalah sama di antara tahun 2014 dan 2015. Terdapat beberapa bulan yang menunjukkan perbezaan peningkatan saiz sukuk pada tahun 2015 berbanding 2014 iaitu pada bulan Februari dan Ogos. Bulan Februari 2015 menunjukkan saiz sukuk mencecah 1000 juta berbanding dengan Februari 2014 iaitu hampir 500 juta. Begitu juga pada bulan Ogos 2015 iaitu hampir 1000 juta juga berbanding Ogos 2014 iaitu hampir 800 juta. Akan tetapi, di akhir tahun 2015 iaitu bulan November menunjukkan sedikit penurunan pada saiz sukuk berbanding pada November 2014. Saiz sukuk pada bulan November 2015 hampir 500 juta berbanding dengan November 2014 iaitu hampir 600 juta.

Penurunan pengeluaran sukuk IILM juga dipengaruhi oleh kelembapan aktiviti ekonomi global dan pematuhan terhadap standard Basel III (Thomson Reuters, 2016). Kelembapan aktiviti ekonomi yang berpunca daripada kejatuhan harga minyak dunia telah menyebabkan kekurangan permintaan terhadap minyak berbanding jangkaan. Kemudian, membawa pula kepada pengeluaran minyak secara berlebihan pada tahun 2015. Hasilnya, harga minyak menjadi murah dan nilai mata wang menjadi rendah. Justeru, kebanyakan negara-negara mengambil keputusan untuk mengurangkan perbelanjaan operasi pelaburan untuk menstabilkan kedudukan nilai mata wang. Kesan daripada keputusan itu menjadikan penerbitan sukuk global makin berkurangan (Mahmoud Kassim, 2016). Pengkaji berpendapat bahawa IILM juga menerima impak yang sama dan seterusnya membuat pengeluaran yang rendah pada akhir bulan November.

Selain itu, penguatkuasaan standard Basel III pula telah memberi tekanan terhadap pelbagai sektor perbankan. Ianya juga telah menghuru-harakan pengurusan kecairan Islam khususnya. IILM juga tidak terkecuali dalam menerima impak ini kerana bukan mudah bagi IKI untuk memenuhi standard Basel III melalui instrumen yang mampu ditunaikan dalam masa 30 hari. Ia perlu menggunakan aset yang mempunyai harga yang stabil, pasaran yang aktif dan besar, risiko pertukaran mata wang yang rendah dan lain-lain lagi. Namun, hanya beberapa instrumen sahaja yang layak memenuhi kriteria yang ditetapkan oleh Basel III. Ini kerana, sistem kewangan Islam telah berhadapan dengan cabaran kekurangan instrumen mudah cair selama 40 tahun. Sebagai natijahnya, pengeluaran sukuk IILM juga berkurangan disebabkan kriteria standard Basel III yang terlalu tinggi untuk diperoleh. 
Secara keseluruhannya, kedua-dua penerbitan iaitu daripada IILM dan IIMM menunjukkan faktor penurunan yang sama iaitu kejatuhan minyak mentah dunia. Namun, pada tahun 2016, IILM mampu untuk meningkatkan penerbitan instrumennya kerana pertambahan aset sandaran yang diterima daripada negara-negara anggota. Sebelum ini, saiz penerbitan instrumen IILM adalah 2 billion sahaja. Tetapi, pada tahun 2016, ia telah bertambah kepada 3 billion. Ini menunjukkan IILM mampu meningkatkan prestasi penerbitan instrumennya dari semasa ke semasa. Ia juga mampu berdiri kukuh untuk mencapai visi dan misinya.

\subsection{ANALISIS KEPERLUAN IILM BERBANDING IIMM}

Malaysia adalah negara terawal yang menubuhkan pasaran wang Islam iaitu pada tahun 1994. Manakala di negara-negara lain, tiada lagi pada ketika itu yang memperkenalkan platform tersebut seperti Malaysia. Bank-bank pusat lain seperti Saudi Arabia dan Kuwait juga hanya menawarkan instrumen berjangka pendek tanpa adanya platform pasaran wang antara bank secara Islam.

Namun, pasaran wang antara bank secara Islam yang telah ditubuhkan sama seperti pasaran wang konvensional iaitu mempunyai cabaran dari segi menyediakan keperluan kecairan dan memenuhi obligasi kewangan untuk memastikan kelancaran aktiviti perniagaan sesebuah bank. Apa yang membezakan antara keduanya adalah memastikan tiada unsur riba, gharar dan segala unsur-unsur larangan dalam muamalat Islam di dalam menyediakan kecairan kepada bank-bank Islam. Tetapi, menjadi suatu kebimbangan juga apabila pasaran wang Islam ini mempunyai limit dalam memberi kecairan kepada bank-bank Islam. Perkara ini terjadi berikutan kekurangan instrumen patuh syariah yang sesuai dan kelemahan infrastruktur yang boleh menyokong keaktifan pasaran wang Islam (Sekoni Abiola Muttalib, 2014).

Walaupun diketahui bahawa IIMM mempunyai banyak instrumen berjangka pendek, namun kebanyakan instrumen-instrumen ini mempunyai suatu kontroversi. Sebagai contoh MITB, NIDC, IAB, masih mengggunakan kontrak bay' inah. IAB menggunakan kontrak bay' ad-dayn, manakala Cagamas Sanadat menggunakan kontrak BBA. Kontrak-kontrak bay' ad-dayn, bay' inah, BBA, tawarruq munazzam tidak lagi diterima oleh majoriti penasihat syariah di peringkat global pada masa kini (Ahmad Sufyan Abdullah, 2015).

Selain itu, terdapat juga kemungkinan isu lain di IIMM iaitu percampuran dana antara IKK dan IKI. Perkara ini boleh terjadi apabila IKK menyertai IIMM untuk melabur dana atau meminjam dana daripada IIMM. Selain itu, ia juga boleh terjadi apabila bank yang menggunakan sistem dwi perbankan menggunakan pasaran IIMM atau sebaliknya. Justeru, terdapat kebimbangan terhadap kepatuhan syariah dari segi menjaga akad dan ciri-ciri asas instrumen IIMM. Jika kepatuhan syariah ini tidak dijaga dengan sebaiknya, ia akan menjejaskan kontrak dan struktur asas instrumen tersebut sebagai instrumen kewangan Islam. Justeru, pertimbangan terhadap implikasi hukum perlu dilakukan dengan berhati-hati kerana tiada peraturan khas yang diperkenalkan oleh IIMM kepada IKI untuk situasi seperti ini. Berbeza dengan negara lain pula, mereka memperkenalkan cukai insentif dan peraturan yang ditambah baik bagi menyokong pembangunan infrastruktur pasaran wang antara bank secara Islam (ISRA, 2016).

Oleh yang demikian, sebagai penggantian terhadap instrumen-instrumen yang mempunyai kontroversi tersebut, terdapat pelbagai penciptaan beberapa instrumen mudah cair yang baru. Instrumen-instrumen baru yang diperkenalkan di pasaran wang Islam iaitu program komoditi murabahah (CMP), murabahah kolateral dan interbank wakalab. Tetapi apa yang berlaku adalah kebanyakan bank-bank Islam di Malaysia juga enggan mencuba alternatif yang baru ini. Sebaliknya IKI lebih suka meluaskan instrumen berasaskan kontrak-kontrak mudarabah dan musharakah. Penolakan menggunakan kontrak-kontrak tersebut kemungkinan atas sebab-sebab 
yang tertentu seperti risiko harga komoditi yang tidak menentu, kos transaksi, kegagalan pembayaran pulangan sebelum tempoh matang, instrumen yang tidak boleh diniagakan, kontrak perkongsian keuntungan (PSIA) yang tiada pulangan yang tetap, kepatuhan syariah, kepatuhan undang-undang dan sebagainya (Othman Cole \& Khaled Soufani, t.t). Ini menyebabkan kebanyakan bank-bank Islam tidak dapat menggunakan kontrak-kontrak terbaru yang disediakan oleh pasaran wang antara bank secara Islam.

Namun, bank-bank Islam memerlukan instrumen-instrumen mudah cair yang berkualiti tinggi dan mampu memberi pulangan tanpa adanya sebarang kerugian. Akan tetapi, bank-bank Islam kini banyak memegang lebihan aset kerana tidak boleh menjangkakan pulangan mereka. Dorongan untuk memegang lebihan aset dalam jangka masa yang lama adalah kerana pulangan yang akan diperoleh itu sedikit mahupun tiada pulangan. Oleh sebab itu, bank-bank Islam kini mempunyai kecairan liabiliti tetapi tidak dari segi aset. Pemegangan lebihan aset tanpa dicairkan adalah suatu kerugian bagi bank kerana tidak memanfaatkan aset dalam tempoh waktu tertentu. Jika IKI masih berterusan untuk tidak menggunakan lebihan dana dengan sebaiknya, ia boleh membawa kepada penurunan pulangan ke atas ekuiti iaitu memberi pulangan yang rendah kepada para pemegang saham bank. Disebabkan hal itu, menjadi suatu keperluan bagi IKI untuk mencari aset pembiayaan yang sesuai atau suatu mekanisme untuk membolehkan kecairan disalurkan (Aznan Hasan, 2011).

Justeru, bank-bank Islam sangat memerlukan instrumen-instrumen mudah cair yang berkualiti tinggi dan memenuhi kepatuhan syariah. Sukuk wakalah IILM adalah satu-satunya sukuk berjangka pendek yang bertaraf A1 yang dapat menjamin pengurusan kecairan merentasi sempadan global. Selain itu, ia adalah instrumen yang mendapat keselarasan fatwa di kalangan pelbagai negara-negara Islam di seluruh dunia. Sukuk IILM mampu memberi pulangan yang sewajarnya dan mampu mengembalikan dana deposit kerana bersandarkan kepada aset kerajaan (IILM, t.t). Oleh yang demikian, bank-bank Islam tidak perlu lagi merasa bimbang dengan pelaburan dana deposit tanpa adanya sebarang pulangan. Sebarang kegagalan pembayaran sukuk pula boleh dicagarkan dengan adanya aset sandaran yang kukuh. Bank-bank Islam juga boleh menjual kembali sukuk IILM kepada pihak ketiga merentasi sempadan global. Ini kerana sukuk IILM ini diniagakan dalam mata wang antarabangsa iaitu dolar. Oleh itu, sukuk IILM mampu memberi keyakinan kepada bank-bank Islam untuk menguruskan kecairan di samping mendapat pulangan yang selayaknya.

\subsection{PENUTUP}

Keperluan terhadap IILM tidak dinafikan oleh kebanyakan komuniti kewangan Islam. Namun, ia masih memerlukan penambahbaikan supaya mampu untuk mencapai mandatnya tersendiri. Dari aspek penerbitan sukuk, ia perlu dipertingkatkan dengan mengambil alternatif lain untuk memperoleh aset sandaran. Dengan adanya penyelesaian terhadap kekurangan aset sandaran bagi penerbitan sukuk, ia akan dapat menyelesaikan pelbagai rantaian masalah yang lain. Selain itu, kewujudan IILM juga tidak akan menggugat peranan pasaran wang antara bank secara Islam (IIMM). Ini kerana IILM dan IIMM mempunyai visi dan misi yang berlainan. Pertamanya IIMM memfokuskan kepada kekurangan dan lebihan kecairan. Manakala, IILM hanya menumpukan kepada lebihan kecairan yang terdapat pada negara-negara anggota. Keduanya, IIMM hanya menguruskan sistem kecairan di Malaysia. Manakala, IILM menguruskan kecairan di peringkat global. Justeru, pasaran seperti IIMM amat diperlukan bagi memenuhi keperluan kecairan IKI di Malaysia. Sebaliknya, kewujudan IILM adalah juga dapat menampung lebihan kecairan di serantau global melalui sukuknya yang berkualiti tinggi dan memenuhi Aset Berkualiti Berkecairan Tinggi (High Quality Liquidity Asset). 


\section{Rujukan}

Ahmad Sufyan Abdullah. (2015). Liquidity Management in Islamic Banks in Malaysia: An Analysis Study from Islamic perspective. (Tesis, PHD). Universiti Yarmouk, Jordan.

Aznan Hasan. (2011). Penggunaan komoditi murabahah sebagai instrumen kecairan di dalam institusi kewangan Islam. Muzakarah Penasihat Syariah Kewangan Islam 2011 Kali Ke-6, Hotel Istana, Kuala Lumpur. Kuala Lumpur.

Dana Kewangan Antarabangsa (IMF). (2015). Islamic Finance: Opportunities, Challenges, and Policy Options.

DDCAP Group. (2014). IILM Issues Second Sukuk Totalling US\$860m and Expands Primary Dealer Network to Boost its Cross Border Islamic Liquidity Management Reach. Diakses pada 19 July 2016, daripada http:/ / www.ddcap.co.uk/iilm-issues-second-sukuk-totalling-us $860 \mathrm{~m}$-and-expands-primarydealer-network-to-boost-its-cross-border-islamic-liquidity-management-reach/

Iam Nazir Ibrahim, temubual, 25 Februari 2016.

IILM. (2016). Information Memorandum.

Islamic Interbank Money Market. (t.t.). IIMM Operation. Diakses pada 13 April 2014. http://iimm.bnm.gov.my/

ISRA. (2016). Islamic financial system: Principles and operations (2nd ed.). Kuala Lumpur: ISRA

Mahmoud Kassim. (2016). The National Business. Diakses pada 6 January, 2016, daripada http://www.thenational.ae/business/economy/sp-says-new-sukuk-issuances-to-decline-this-year

Mohd Daud Bakar, temubual, 9 Jun 2016.

Mohd Kamal Abdul Karim, temubual, 14 Mac 2016.

Musa Hasan Abdul Basser, temubual, 11 April 2016.

Nazim Mohd Nor, temubual, 7 Mac 2016.

Obyatullah Ismath Bacha. (2008). The Islamic inter bank money market and a dual banking system: The Malaysian experience. Munich Personal Repec Archive, 4.

Othman Cole \& Khaled Soufani (t.t). Commodity murabahah transactions (cmt): a short-term liquidity management tool in Islamic banks.

Ramadhan Fitri Ellias, temubual, 8 Mac 2016.

Rupa Damodaran (2016). Moody's: Sukuk issuance slowed, but Islamic banking growth still strong. Diakses pada 5 November 2016, daripada https://sg.finance.yahoo.com/news/moodys-sukukissuance-slowed-islamic-053711921.html

Sekoni Abiola Muttalib. (2014). Islamic Money Market: An Instrument for Managing Liquidity Risk in Islamic Banks. Islam and Civilisational Renewal (ICR), 5(2), 204-224.

Thomson Reuters. (2016). Liquidity Management Through Sukuk Innovative Solution. Diakses pada 14 Oktober 2015, daripada https:/ / ceif.iba.edu.pk/pdf/ThomsonReutersLiquidityManagementThroughSukukInnovativeSolutions.pdf 